\title{
Problems and Obstacles in Learning English as a Foreign Language
}

\author{
Choosri Banditvilai and Robert Cullen
}

\begin{abstract}
The purpose of this study is to identify the main problems and difficulties of non-English major students at Kasetsart University, Kamphaeng Saen Campus, and to make subsequent recommendations. The approach has been to provide a questionnaire to 520 students from a broad range of disciplines at Kasetsart University to gain details of their main difficulties in learning English. The findings indicate that, writing was generally thought to the biggest problem area followed by listening. Results also indicate that the great majority of students do not study or practice English on a daily basis. This study concludes with recommendations for 'Writing' courses, focusing on basic grammar structures to be introduced and for a comprehensive 'Listening' course to be added to the curriculum. The question of student motivation is considered as pivotal in this discussion and the study ends with a call for further research to be conducted in this field.
\end{abstract}

Index Terms-Problems, English as a foreign language, English competence, motivation.

\section{INTRODUCTION}

English has long been recognized as a global language of importance and has been studied as a second language in Thailand for over a hundred years. King Rama IV himself studied and was able to speak it competently. More recently its value and prominence has increased to a far greater degree due to globalization. Schools and universities across the country have outlaid huge resources in developing English courses and programs.

Despite the great effort spent in developing a general competency in English among Thai students over recent years the results have been mixed. A 2015 worldwide ranking of EFL proficiency undertaken by Education First (EF), placed Thailand at number 62 out of 70 . Other countries in the region rated were: Singapore 12, Malaysia 14, Vietnam 29, Indonesia 32 and Cambodia 69. Clearly Thailand is lagging behind in its EFL proficiency.

All university students in Thailand are required to undertake a foundation EFLcourse in order to provide a basic

Manuscript received September 8, 2018; revised November 12, 2018 This work has been funded by the department of English, Faculty of Liberal Arts and Science, Kasetsart University, Kamphaeng Saen Campus.

Choosri Banditvilai and Robert Cullen are with the Department of English, Faculty of Liberal Arts and Science, Kasetsart University, Kamphaeng Saen Campus, Nakhon Pathom 73140, Thailand (e-mail: cbanditvtlai@yahoo.com, Cullen.bob@gmail.com) competency in the language. It is recognized that the non-English major students are generally less competent in English than English major students and that they face different is sues in studying EFLrelating to study background.

\section{Literature Review}

There is a wide range of literature focusing on issues relating to current problems faced by Thai EFL students. For the purposes of this review, they have been divided into three categories following Jindathai [1] who attempts to identify and find solutions to Thai students' English learning difficulties. The study identifies three main areas which need attention as: (1) management by teachers; (2) exposure to real English speaking situations; and (3) the individual personality of the student.

\section{A. Management by Teachers}

According to Kaewdang [2], the Thai educational system has long emphasized a "chalk and talk" pedagogy, with an emphasis on rote learning that places an importance on teacher centered classroom instructions. These traditional teaching approaches directly influence the learning styles of the students. Under this system students easily get used to the idea of being passive learners prepared to be receivers rather than discoverers of knowledge.

Teaching methods in Thailand are also considered to be a significant obstacle to students' development [3]. She claims that Thai teachers continue to follow a teacher-centered method of teaching with a heavy emphasis on grammar over speaking practice. A particular concern for university students is emphasized by Pawapatcharaudom [4] who shows that the learning styles between high school and university are very different. Whereas in high school students are encouraged to learn passively this doesn't prepare them for the active participation which will be demanded of them in university. Consequently, this leads to confusion and stress which adds to the students' learning problems.

Sawir [5] considers the cultural learning differences between Asian and Western teaching styles in the Australian context. She highlights how Asian students have ingrained learning difficulties relating to a previous teacher centered learning culture. She shows how there is a clear need to improve teaching practices in their home countries.

Miao [6] also highlights the culturally related question of how Thai students tend to relate submis sively to their foreign English teachers which can create a lack of clear understanding in learning situation.

Similar views are expressed by Somdee [7]. Their initial findings affirmthe idea that a big obstacle to learning English was that students found the traditional methods of study 
boring. For these reasons, they have developed a technology based learning method designed to enhance students' interest and the learning experience. In this program students are required to develop a story telling technique which makes use of windows movie maker. This use of technology has been found to increase the students' interest in the learning process encouraging them to become more active and self-motivated. Recommendations made for teachers as a result of this experience are that every effort should be made to increase the use of web-based computer technology to enhance the students' learning experience.

Teaching methods have also been discussed by Scott [8] who identifies the idea that study techniques have traditionally emphasized memorization of grammar rules to the detriment of the spoken word.

In addition, Kamprated [9] describes how students suffer from anxiety due to the fear of making mistakes and being laughed at by their peers or receiving negative feedback from the teacher. This in turn has a negative impact preventing them from openly taking part in speaking practice.

Saengpakdeejit [10] raises the issue of the importance of vocabulary learning in language acquisition. He shows how developing vocabulary is crucial to understanding and calls for teachers to focus more on this issue in classroom situations.

The need for a higher proficiency among English language teachers is also recognized by Khunsamrong [11] as an important factor relating to students' progress. On a positive note, Noom-ura [12] has described how teachers showed openness to possibilities of developing their careers through teacher training programs that would improve their teaching proficiency.

\section{B. Individual Personality}

Personal skills and needs are commonly seen to impact on students' abilities and capacities to study. In regard to this, Pawapatcharaudom [4] makes some important observations. Her studies show that writing skills, particularly when under time pressure are seen as being the biggest obstacle faced by students. An interesting observation made here is that she claims many students prefer to write in Thai and then translate into English. Such practices are sure to present obstacles to natural fluency. To help overcome problems as sociated with writing particularly grammar difficulties. Peer feedback and advises continued ongoing monitoring of students' individual needs [4].

Watcharapunyawong and Usaha [13] also highlight the problem of Thai university students applying Thai grammar and modes of writing when composing essays in English. It is seen as important here for students to overcome the strong tendency to relate to their first language while writing in a second one.

In the same way, Khan, \& Khan [14] also address the problem of EFL students unconsciously using their first language. Learners can easily get into the habit of using their mother tongue, and in this way they face further obstacles in learning English.

This idea of personal needs has been linked in part to contributing cultural factors. This is described by Yusica [3] who shows how Thai students faced particular difficulties related to socio-cultural factors peculiar to Thailand which inhibited their oral communication skills. She claims that these factors of constraint are a result of Thailand never having been colonized, resulting in psychological attitudes of anxiety, uneasiness, frustration, self-doubt, apprehension, fear of mistakes, shyness, lack of confidence and motivation. If her findings are correct this may have wide ranging implications for developing positive psychological approaches to study methods for Thai foreign language students.

\section{Exposure to Speaking Situations}

Numerous researchers have identified the need for students to have a greater opportunity to practice speaking in class and in real life situations.

The need to adopt maximum speech time in learning situations has been identified by Scott [8]. He finds that pronunciation is a big issue owing to a number of the English sounds not being found in Thai. Secondly grammar is a difficulty as English has a very different grammar structure to Thai. He suggests that these difficulties can best be overcome by increasing speaking practice. This point is also made by Somdee [7] who describe how students lack the confidence to speak in class and the opportunity to speak regularly with foreigners. These two factors of speaking skills and motivation are key ideas discussed by Ali [15]. In his study he shows again that Thai students' biggest obstacles lie in overcoming problems relating to speaking skills. He focuses on the difficulty of pronunciation which Thai students face as English demands pronunciation of certain sounds that Thai doesn't use. He also finds that Thai students lack motivation in learning English as they find the subject matter boring and it has little use in their daily lives.

Cubalit [16] describes how university students in Thailand have very little opportunity to practice spoken English resulting in very poor listening and speaking skills. He calls for teachers to enhance listening skills practice to assist their students in developing their listening skills.

The requirements of first year English major and non-English major university students have been highlighted by Khunsamrong [11] who emphasizes the need for students to have the opportunity to practice with native speakers.

Noom-ura [12] has also shown how high school teachers generally consider that students should seek more opportunities to practice the language and develop their confidence levels. It was a lack of students' opportunities to use English, along with a limited background in the language that were seen as the greatest inhibiting factors towards students' learning.

The conclusion of the study by Jindathai [1] was that, in order to increase students' exposure to real speaking situations and thereby increase their confidence, trips should be arranged to visit tourist areas and interviews should be arranged with tourists. Another recommendation was that English camps should be organized to provide a supportive atmosphere whereby students could be encouraged to speak without fear of making mistakes. Jindathai [1] also recommends that students travel abroad to other ASEAN countries to study in language schools. As for changes to 
classroom teaching he advises activities such as storytelling and role-plays to enact real life situations and increase students' confidence.

Clearly the opportunity to practice with native speakers would be motivational. It should be emphasized that this needs to be done on a regular basis and in a structured way that would reinforce lessons previously covered in class. In this way students would develop more complete language skills giving a practical aspect to lessons previously studied.

\section{Summary}

The various studies outlined above have contributed a number of useful considerations to the discussion relating to problems faced by ThaiEFLstudents. The problems identified are of various types, from pronunciation and speaking skills, to grammar, writing capabilities, socio-cultural issues, teaching methods and opportunities to practice in real life. Most of these studies have focused on specific groups of students in certain study situations. It can be expected therefore that conclusions would differ to a certain extent. Perhaps an area of attention that has been underplayed in these studies is that of student motivation. When we begin to understand what really motivates students to succeed and perform to their highest ability, then we will be in a position to approach the is sues of particular language skills and needs on a more secure footing. It is our hope in this study of the needs of English non-major students at Kasetsart University to identify their particular needs and motivations and to make recommendations concerning them.

\section{PROCESS}

This section will include details on the participants, being students at Kasetsart University; the instruments, being a questionnaire and follow-up interviews; the method of data analysis; and the findings.

\section{A. Participants}

The participants consisted of 520 first year non English major students including 292 females and 228 males. They were from the faculties of Liberal Arts and Science, Fishery, Sports Science, Engineering and Agriculture at Kasetsart University, Kamphaeng Saen campus. The participants were selected through simple random sampling. The recruited participants formally indicated their consent to participate as respondents in this study. All students were also informed that their identity would be kept anonymous.

\section{B. Instruments}

This study used a questionnaire to survey problems and obstacles found by the first year non English major students who studied Foundation English 1 at Kasetsart University, Kamphaeng Saen Campus. The questionnaire was divided into 2 parts. The first part was general questions about the participants' English language skills and background. The second part was an asses sment of the participants' difficulties in the four language skills based on a five-point Likert scales. To provide further support, 50 students from 5 faculties were randomly selected for a semi-structured interview at the end of the experiment. Students were asked for their opinions on problems and obstacles in learning English in terms of motivation, opportunity and attitude. The interviews were recorded, transcribed and coded with similar themes categorized.

Examples of research questions and instruments

TABLE I: EXAMPLES OF RESEARCH QUESTIONS AND INSTRUMENTS

\begin{tabular}{lc}
\hline \hline Questions & Instruments \\
\hline 1. What are the problems and obstacles faced & Questionnaire \\
by the first year non English major students & \\
in learning English? & \\
$\begin{array}{l}\text { 2. What are the factors affecting the students' } \\
\text { listening, speaking, reading and writing? }\end{array}$ & $\begin{array}{c}\text { Semi structured } \\
\text { interview }\end{array}$ \\
\hline \hline
\end{tabular}

Table I provides some examples of the research questions and instruments used in this study.

\section{Data Analysis}

The researcher analyzed the data by using a program called Statistical Package for Social Science (SPSS). Also the means (M), and standard deviation (SD) were the basic descriptive statistical analysis to describe the outcome of students' problems and obstacles in the four language skills.

T ABLE II: NUMBER AND PERCENTAGE OF PARTICIPANTS

\begin{tabular}{ccc}
\hline \hline Faculty & Number of students & Percentage \\
\hline Arts and Science & 194 & 37.3 \\
Fishery & 34 & 6.5 \\
Sports Science & 56 & 10.8 \\
Engineering & 165 & 31.7 \\
Agriculture & 71 & 13.7 \\
Total & 520 & 100.0 \\
\hline \hline
\end{tabular}

Table II shows that the majority of students who participated in this study were from two faculties. Firstly, the Faculty of Liberal Arts and Science. Secondly, the Faculty of Engineering. The remaining students were from three other faculties at the university, namely the Faculties of Agriculture, Sports Science and Fishery.

T ABLE III: NUMBER OF YEARS SPENT LEARNING ENGLISH

\begin{tabular}{ccc}
\hline \hline Number of years & Number of students & Percentage \\
\hline 11 years & 29 & 5.6 \\
12 years & 60 & 11.5 \\
13 years & 86 & 16.5 \\
14 years & 232 & 44.6 \\
15 years & 55 & 10.6 \\
16 years & 42 & 8.1 \\
17 years & 8 & 1.5 \\
18 years & 4 & 0.8 \\
Others & 4 & 0.8 \\
Total & 520 & 100 \\
\hline \hline
\end{tabular}

Table III indicates that all of the students in the survey had studied English for a minimumof 11 years, while approximately two-thirds of the students had studied a minimum of fourteen years. 
TABLE IV: AMOUNT OF ENGLISH SPOKEN

\begin{tabular}{ccc}
\hline \hline Frequency & Number of students & Percentage \\
\hline None & 116 & 22.3 \\
Daily & 90 & 17.3 \\
Once a week & 210 & 40.4 \\
Once a month & 51 & 9.8 \\
Other & 53 & 10.2 \\
Total & 520 & 100 \\
\hline \hline
\end{tabular}

Table IV reveals the largest amount of the students at $40.4 \%$ spoke English once a week, $22.3 \%$, had no chance at all to speak English, $17.3 \%$ spoke English daily, $9.8 \%$ once a month and others $10.2 \%$.

TABLE V: Key DifFICULTIES LEARNING ENGLISH ACCORDING TO GENDER

\begin{tabular}{ccccccc}
\hline \hline Gender & Grammar & $\begin{array}{c}\text { Pronunciatio } \\
\mathrm{n}\end{array}$ & $\begin{array}{c}\text { Spellin } \\
\mathrm{g}\end{array}$ & Vocabulary & Other & Total \\
\hline Female & 115 & 27 & 8 & 101 & 41 & 292 \\
Male & 81 & 17 & 6 & 84 & 40 & 228 \\
Total & 196 & 44 & 14 & 185 & 81 & 520 \\
\hline \hline
\end{tabular}

Table V clearly shows that grammar and vocabulary were the two greatest areas of difficulty for both male and female. The male students listed vocabulary as slightly more difficult than grammar while with the female students it was first grammar and then vocabulary. Significantly both groups placed pronunciation higher than spelling in order of difficulty. This would seem to indicate a need for greater exposure pronunciation practice.

T ABLE VI: DESCRIPTIVE STATISTICS

\begin{tabular}{|c|c|c|c|c|c|}
\hline & No. & Min. & Max. & Mean & SD. \\
\hline \multicolumn{6}{|l|}{ Listening } \\
\hline Do not know the vocabulary & 520 & 0 & 5 & 3.54 & .834 \\
\hline $\begin{array}{c}\text { Do not catch the meaning in } \\
\text { time }\end{array}$ & 520 & 0 & 5 & 3.56 & .880 \\
\hline Do not understand the accent & 520 & 0 & 5 & 3.45 & .915 \\
\hline Cannot get the main idea & 520 & 0 & 5 & 3.25 & .872 \\
\hline $\begin{array}{l}\text { Cannot distinguish the sounds } \\
\text { of similar words }\end{array}$ & 520 & 0 & 5 & 3.55 & .911 \\
\hline \multicolumn{6}{|l|}{ Speaking } \\
\hline No vocabulary & 520 & 0 & 5 & 3.55 & .872 \\
\hline $\begin{array}{c}\text { Afraid of making grammar } \\
\text { mistakes }\end{array}$ & 520 & 0 & 5 & 3.73 & .937 \\
\hline Need to think in Thai first & 520 & 0 & 5 & 3.74 & .983 \\
\hline Embarrassed to speak & 520 & 0 & 5 & 3.40 & 1.039 \\
\hline $\begin{array}{c}\text { Afraid to mispronounce } \\
\text { words }\end{array}$ & 520 & 0 & 5 & 3.39 & 1.021 \\
\hline \multicolumn{6}{|l|}{ Reading } \\
\hline $\begin{array}{c}\text { Lack of vocabulary causing } \\
\text { misunderstanding }\end{array}$ & 520 & 0 & 5 & 3.71 & .908 \\
\hline Must first translate into Thai & 520 & 0 & 5 & 3.64 & .899 \\
\hline $\begin{array}{c}\text { Do not have any strategies } \\
\text { for reading }\end{array}$ & 520 & 1 & 5 & 3.32 & .921 \\
\hline $\begin{array}{l}\text { Do not understand the } \\
\text { grammar or structure }\end{array}$ & 520 & 1 & 5 & 3.65 & .879 \\
\hline $\begin{array}{l}\text { Cannot comprehend meaning } \\
\text { and main points of the } \\
\text { passage }\end{array}$ & 520 & 0 & 5 & 3.35 & .874 \\
\hline
\end{tabular}

\begin{tabular}{cccccc}
\hline Writing & 520 & 1 & 5 & 3.86 & .878 \\
$\begin{array}{c}\text { Have only a small vocabulary } \\
\text { Not sure of the grammar }\end{array}$ & 520 & 0 & 5 & 3.99 & .837 \\
$\begin{array}{c}\text { Always think in Thai first and } \\
\text { then translate into English } \\
\begin{array}{c}\text { Cannot write sentences } \\
\quad \text { grammatically }\end{array}\end{array}$ & 520 & 1 & 5 & 3.82 & .832 \\
$\begin{array}{c}\text { Do not know sentence } \\
\text { structure }\end{array}$ & 520 & 1 & 5 & 3.79 & .834 \\
\hline \hline
\end{tabular}

Table VI shows that over the four language skills, students generally felt their greatest problems were related to writing and then listening. Speaking was felt to be less of a problem and reading least of all. The main difficulty perceived in writing was that students were unsure of grammar structures. This is followed having a small vocabulary, thinking first in Thaibefore writing, being unable to compose a sentence, and not knowing the structure of a sentence. Students indicated their particular listening difficulties were in catching the meanings of sentences in time and in differentiating between similar sounding words. Speaking skills were recorded third in the order of difficulty. The students' main difficulty was the need to think in Thai first. This was followed by a fear of making grammar mistakes, lacking vocabulary, and being shy of making mispronunciations. For 'reading skills' students indicated that their biggest problem was having a small vocabulary. This was followed by not understanding the structure and grammar. Next was the need to translate into Thai first, grasping the meaning and failing to see the main idea. The lack of reading strategies was seen as least important. It is suggested here that reading is the most passive and least threatening of the four skills. It may be therefore considered by the students to be the area of least difficulty.

\section{CONCLUSIONS}

Fromthe above findings, it can be concluded that 'writing' was perceived to be the students' main problem due to a general difficulty in understanding the complexities of the grammar.

'Listening' was felt by the students to be second in order of difficulty. 'Speaking' skills were considered to be third overall. Students' main concern in this area was again one of making grammar mistakes while pronunciation was not felt to be a major difficulty.

'Reading' was seen to be the area of least concern by the students. A lack of sufficient vocabulary was felt to be their biggest problemin this field while reading strategies were felt to be of least importance.

The results of the semi-structured interview reveal that one of the main problems in learning English is that the students lack opportunities to speak English in their daily life and therefore motivation to learn.

Perhaps of most significance to this study has been the revelation that the great majority of students do not study or practice English on a regular daily basis. A limitation of this study has been in the area of 'motivation'. It is recommended that further research in this field be carried out. 


\section{DISCUSSION AND RECOMMENDATIONS}

In the area of writing a more thorough training in grammar is recommended. It is suggested here that as writing provides a more permanent record of students' abilities, the fear of making a mistake may be heightened. Clearly students need more writing grammar practice and tuition than they are currently receiving. It may seem surprising that 'Listening' was considered to be a major problem, given that listening to music was the preferred learning method of almost half of the participants. Listening to music, however, may at best be viewed as being a passive study method whereby students enjoy the tunes and melodies rather than concentrate seriously on the precise meaning of the lyrics. Another problemhere is that the lyrics of songs often don't follow the usual pronunciation, vocabulary or grammar rules, making them misplaced in the normal spoken context. Meaningful listening practice would have to include regular listening to audios of natural spoken voices in a variety of accents accompanied by comprehension exercises of graded levels of difficulty. There may be a strong argument here for purely 'Listening' classes to be included in curriculums. This would be parallel to 'Listening \& Speaking' classes which focus on conversation skills.

As for Students' lack of concern regarding pronunciation other authors have felt that pronunciation was an area of high concern due to the numerous sounds in English which aren't so differentiated in Thai. It might also be argued that each nationality has its own unique English accent and that the Thai accent should be seen in that context.

Accents aside it should also be recognized that there is a difference between a unique accent and poor pronunciation. Studies have shown that people learn the basic sounds of a language easily in childhood but find them more difficult to learn as adults. This may be an argument for native speakers to be involved in language teaching in schools from early nursery classes and up through the early schooling years.

'Reading' was considered to be the area of least concern by the students This perhaps represents an understanding that it is felt to be the least demanding in terms of output.

The perceived lack of vocabulary by the students provides a strong argument for reading practice that focuses on vocabulary to be emphasized in any English learning program. This would lead to a natural and progres sive development of a wide vocabulary.

Students' lack of regular daily practice suggests a serious motivation problem. This question of motivation may be considered in a different category to other problems and obstacles as it does not relate to 'ability' but to 'desire'. On this point three things may be suggested. Firstly it may be argued that if the students have encouragement and recognition for their achievements they would be more likely to push themselves to succeed. Secondly, students should be taught to set themselves personal goals in terms of how far they wish to progress on a daily and weekly basis. Thirdly, it is becoming increasingly clearer that technological innovations in the field of language acquisition are having and will continue to have a major impact on the ways in which students are motivated. The more educators can enhance the use of these resources in productive ways the more students will benefit by them.

A final recommendation arising from this study would be a call for realistic but consistent national goals, not based upon piling more and more homework on students' already heavy workloads, but upon developing a sound and solid infrastructure based upon a practical and realistic curriculum for all.

\section{ACKNOWLEDGMENT}

The authors would like to thank the department of English at the Faculty of Liberal Arts and Science, Kasetsart University, Kamphaeng Saen campus for funding and supporting this research project. Special thanks goes to Assistant Professor Chada Kongchan for valuable consultation.

\section{REFERENCES}

[1] S. Jindathai, "Factors affecting English speaking problems among engineering students at Thai- Nichi Institute of Technology," College of General Education and Languages Thai-Nichi Institute of Technology, Bangkok, Thailand, 2015.

[2] R. Kaewdang. (1999). Learning for the New Century. [Online]. Available: http://www.edthai.com/reform/jan20e.htm

[3] U. Yusica, "Problems Faced by Thai Student s in Speaking English". Faculty of Education, English Dept., State Islamic Institute of Tulungagung, Thailand, 2014.

[4] R. Pawapatcharaudom, "An investigation of Thai Students' English language problems and their learning strategies in the international program at Mahidol University," MA thesis, Department of Language, King Mongkut's Institute of Technology North Bangkok. Bangkok, Thailand, 2017.

[5] E. Sawir, "Language difficulties of international students in Australia: The effects of prior learning experience," International Education Journal, vol. 6 no. 5 p. 67, 2005.

[6] L. Miao, "A study of English communication problems between Thai students and foreign English teachers in suwanplubplapittayakom school," MA thesis, Thammasat University, Bangkok, Thailand, 2011.

[7] M. Somdee, "Developing English speaking skills of Thai undergraduate students by digital storytelling through websites," MA thesis, School of Foreign Languages. Institute of Social Technology. Suranaree University of Technology, Thailand 2012.

[8] R. Scott. (2006). TEFL Problems faced by Thai Students Learning English. [Online] Available: https://www.teflcorp.com/ articles/ 46-tefl-problems-learning-english-different-countries/143-proble ms-faced-by-thai-students-learning-english/

[9] N. Khamprated, "The problems with the English listening and speaking of students studying at a private vocational school in Bangkok Thailand," M.A. thesis, Srinakharinwirot University, Bangkok, Thailand, 2012.

[10] R. Saengpakdeejit, "Strategies for dealing with vocabulary learning problems by Thai University Students," Silapakorn University Journal of Social Science, Humanities, and Arts, vol. 14 no. 1 pp. 147-167, 2014.

[11] S. Khunsamrong, "A study of the problems faced by Thai Students in acquiring English with specific reference to the first year students at the northern campus of Mahachulalongkornrajavidyalai University," Thailand, 2013.

[12] S. Noom-ura, "English-teaching problems in Thailand and Thai teachers' professional development needs," Journal of English Teaching, vol. 6, no. 11, 2013. 
[13] S. Watcharapunyawong and S. Usaha, "Thai EFL students' Writing errors in different text types: the interference of the first language," English Language Teaching, vol. 6, no. 11, 2013.

[14] T. J. Khan and N. Khan, "Obstacles in learning English as a second language among intermediate students of districts Mianwali and bhakkar, Pakistan," Open Journal of Social Science, vol. 4, pp. 154-162, 2016.

[15] N. E. Ali, "A study on problems faced by Thai students in learning English in UniSZA, Malaysia," presented at the third International Conference on Languages and Society, Bangkok, Thailand, 2013.

[16] A. N. Cubalit, "Listening comprehension problems of Thai university English learners," in Proc. the Third International Conference on Language, Literature \& Society," pp. 207-214. Sri Lanka, 2016

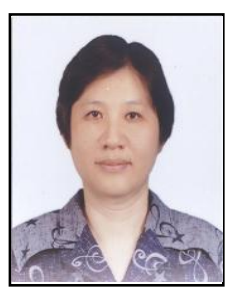

Choosri Banditvilai was born in Bangkok, Thailand. She got a bachelor degree in English from Silpakorn University in 1985. In 2003, she got a master degree in Applied Linguistics from King Mongkut University of Technology, Thonburi in Thailand. Presently, she is an Assistant Professor at the Department of English, Faculty of Liberal Arts and Science, Kasetsart University,
Kamphaeng Saen Campus, Nakhon Pathom in Thailand. She is currently teaching Business English and Reading courses. She is the author of English for Athletes and Referees (2017), Pathways to Opportunity through English (2014), Read All About It: English in Newspapers (2010) and Authentic English Texts for Advanced Learners (2003). All of these books are published by Kasetsart University Press in Thailand.

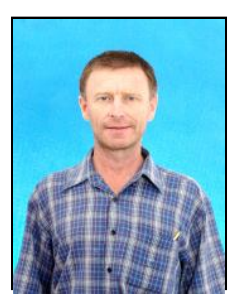

Mr. Robert Cullen is originally from London and grew up in Perth, Australia. He received a degree in Asian Studies and later a Graduate Diploma in Secondary Education from Murdoch University In Perth. He now teaches English at Kasetsart University, Kamphaeng Saen Campus, Nakhon Pathom in Thailand where he has lived for 25 years. 